\title{
Peranan Kemampuan Manajerial Kepala Sekolah Dalam Rangka Meningkatkan Mutu Pendidikan Di Tingkat Sekolah Dasar Kecamatan Mandai Kabupaten Maros
}

\author{
Andi Nurochmah ${ }^{1}$, M. Bachtiar ${ }^{2}$, Syamsurijal Basri ${ }^{3}$ \\ 1,2,3Program Studi Administrasi Pendidikan Fakultas Ilmu Pendidikan Universitas Negeri Makassar \\ 1andi.nurochmah@gmail.com \\ 2m.bachtiar@unm.ac.id \\ ${ }^{3}$ syamsurijal.basri@unm.ac.id
}

\begin{abstract}
The problem in this research is how the school principals management ability in order to improve the quality of elementary school education in the District Mandai Maros?. The objective in the study is to describe the school principals management skills in order to improve the quality of elementary education in the District Mandai Maros. This research is quantitative descriptive, the population of all teachers and members of the study sample, only 60 teachers from elementary, data was collected using a questionnaire, documentation. Then the data is analyzed using percentages. The results showed that the competency of school principals average category both in terms of planning, organizing, Directing. Although in this element there are not enough in the maximum or category Briefing teachers who have difficulties in the learning process.
\end{abstract}

Keywords: management ability, quality of education, principals

\section{PENDAHULUAN}

Pendidikan sebagai sarana vital dalam pengembangan SDM, merupakan suatu kebutuh-an yang tidak dapat dipisahkan dari kehidupan manusia dalam mencerdaskan kehidupan bangsa dan membentuk manusia terampil di bidangnya. Pendidikan dalam arti bahasa disebut proses melatih dan mengembangkan pengetahuan, ketrampilan, pikiran, perilaku,dan lain-lain terutama oleh sekolah formal. Pendidikan dalam pengertian ini, dalam kenyataannya, sering dipraktekkan dengan pengajaran yang sifatnya verbalistik. Mulyasa (2004:3) menyatakan bahwa perwujudan masyarakat berkualitas menjadi tanggung jawab pendidikan, terutama dalam mempersiapkan peserta didik menjadi subjek yang makin berperan menampilkan keunggulan dirinya yang tangguh, kreatif, mandiri dan professional pada bidangnya masing-masing. Upaya meningkatkan kualitas pendidikan terus-menerus dilakukan baik secara konvensional maupun secara inovatif. Sekolah yang dikelola dengan baik, dari segi pembelajar-an, sumber daya manusia dalam hal ini pendidik serta manajemennya maka sekolah akan menghasilkan output (siswa) yang berkualitas yang mampu bersaing ditempat yang lebih besar tantangnya dan lebih komplek. Sedangkan, sekolah yang manajemennya kurang baik tidak akan memberikan kualitas dan lulusan yang baik. Banyak sekolah yang tidak terkelola dari segi sistem pembelajaran dan manajemen-nya sehingga sekolah tersebut tidak maju dan tidak mampu bersaing dalam industri pendidikan saat ini.

Untuk mewujudkan sekolah idaman dan sekolah yang memenuhi kebutuhan masyarakat dibidang pendidikan. sekolah atau lembaga pendidikan membutuhkan sumber daya manusia yang profesional. Dengan adanya sumber daya manusia sekolah dapat memberikan konstribusi yang menguntungkan bagi terseleng-garanya pendidik-an yang efektif. Oleh karena itu, kepemimpin kepala sekolah harus mampu memobilisasi sumber daya sekolah, dalam kaitannya dengan perencanaan dan evaluasi program sekolah, pengembangan kurikulum, pembelajaran,pengelolaan ketenagaan, sarana dan prasarana, sumber keuangan, pelayanan siswa, hubungan sekolah dan masyarakat dan penciptaan iklim sekolah. Lebih lanjut Mulyasa (2003:103) menerangkan bahwa peran kepala sekolah sebagai manajer, kepala sekolah harus mampu mendaya-gunakan seluruh sumber daya sekolah dalam rangka mewujudkan visi dan misi untuk mencapai tujuan yang telah ditetapkan.

Selain itu, kepala sekolah harus mampu menghadapi berbagai persoalan disekolah, 
berpikir secara analitik dan konseptual dan harus senantiasa berusaha untuk menjadi guru penengah dalam memecahkan berbagai masalah yang dihadapi oleh para tenaga kependidikan yang menjadi bawahannya, serta berusaha untuk mengambil keputusan yang memuas-kan bagi semua. Dengan demikian, Maka kepala sekolah harus mampu menjabarkan fungsi dan tujuan Pendidikan Nasional kedalam tujuan yang lebih rinci lagi. Dengan kata lain tujuan menjadi lebih sederhana dan dapat dijalankan. Dalam hal ini peran kepala sebagai manajer,yaitu kepala sekolah dituntut untuk bisa dan mampu member-kan pelayanan pendidikan dengan baik sesuai dengan yang diharapkan masyarakat. Kepala sekolah tidak perlu raguragu dalam membuat strategi dan kebijakan sendiri. Secara umum untuk meningkatkan mutu sekolah untuk mencapai standar kompetensi harus ditunjang oleh banyak pendukung. Diantaranya adalah, kepala sekolah dan guru profesional merupakan salah satu input sekolah yang memiliki tugas dan fungsi yang sangat berpengaruh kepada berlangsungnya proses pendidikan.Oleh karenanya, diperlukan kepala sekolah yang professional,sebagai pemenuhan sumber daya manusia yang baik serta memiliki kompetensi yang mendukung tugas dan fungsi-nya dalam menjalankan proses pendidikan pada satuan pendidikan.

Disamping peran kepala sekolah dalam meningkatkan mutu pendidikan ada faktor pendukung lainnya yang dapat menentukan mutu pendidikan, seperti sarana dan prasarana, kurikulum dan proses belajar mengajar.Kepala sekolah sebagai manajer sudah saatnya mengoptimalkan mutu kegiatan pembelajaran untuk memenuhi harapan pelanggan pendidikan. Sekolah berfungsi untuk membina sumber daya manusia yang kreatif dan inovatif, sehingga kelulusannya dapat memenuhi kebutuhan masyarakat,baik pasar tenaga kerja sector formal maupun sektor informal.Para manajer pendidikan dituntut mencari dan menerapkan suatu strategi manajemen baru yang dapat mendorong perbaikan mutu sekolah.

Sebagai manejer, kepala sekolah dituntut mampu membuat perencanaan, pengorganisasian, pengarahan serta pengawasan. Untuk itu, kepala sekolah wilayah Kecamatan Mandai Kabupaten Maros dituntut untuk selalu membuat perencanaan dan program kerja, mengingat pendidikan selalu membutuhkan pengembangan dalam peningkatan mutu pendidikan. Maka, peran manajer dalam hal ini adalah kepala sekolah, sangat dituntut untuk senantiasa mampu dan bisa mengembangkan sekolah. baik, dari penyiapan profesionalisme tenaga pendidiknya, penyediaan sarana dan prasana sampai dengan kepuasaan pelayanan sekolah terhadap pelanggan sekolah.

Ini bukanlah pekerjaan mudah bagi seorang kepala sekolah yang dituntut untuk menjadi seorang manajer. Tidak semua guru atau pendidik mampu menjadi kepala sekolah, oleh karena itu kepala sekolah senantiasa dituntut dengan profesional dan kompetensi kinerja sebagai seorang manajer. Karena, apapun kinerja kepala sekolah tidak terlepas dari pantauan dan penilaian dari semua pihak dan begitu kompleksnya kerja dan ruang lingkup tugas kepala sekolah dan diikuti oleh perkembangan yang dialami oleh SD di wilayah Kecamatan Mandai, berdasarkan temuan tersebut di atas maka penulis merasa perlu untuk meneliti peranan kompetensi manajerial kepala sekolah, dalam meningkatkan mutu pendidikan di Sekolah Dasar wilayah Kecamatan Mandai.

Dengan demikian pendidikan yang bermutu tidak hanya dilihat dari kualitas lulusannya, akan tetapi bagaimana sekolah tersebut mampu memenuhi kebutuhan pelanggan sesuai dengan standar mutu yang berlaku. Pelanggan dalam hal ini adalah pelanggan internal (Pendidik) serta eksternal (Peserta didik,orang tua, dan masyarakat). Atas dasar permasalahan tersebut di atas, maka penelitian ini perlu dilakukan secara lebih lanjut berkaitan dengan : Peranan Kemampuan Manajerial Kepala Sekolah dalam Rangka Meningkatkan Mutu Pendidikan di SD Kecamatan Mandai Kabupaten Maros."

Berdasarkan permasalahan yang telah diuraikan di atas, maka rumusan masalah dalam penelitian adalah sebagai berikut:“ Bagaimana-kah gambaran Peranan Kemampuan Manajerial Kepala Sekolah dalam Rangka Meningkatkan Mutu Pendidikan di SD Kecamatan Mandai Kabupaten Maros? sedangkan tujuan dalam penelitian iri adalah: untuk mendapatkan gambaran Peranan Kemampuan Manajerial Kepala Sekolah dalam Rangka Meningkatkan Mutu Pendidikan di SD Kecamatan Mandai Kabupaten Maros?

\section{METODE PENELITIAN}

\section{a. Pendekatan dan Jenis Penelitian}

Pendekatan penelitian yang diguna-kan dalam penelitian ini adalah pendekatan yang bersifat deskriptif. Sedangkan jenis peneliti-an 
dalam penelitian ini adalah termasuk jenis penelitian deskriptif kuantitatif

\section{b. Peubah Penelitian}

Peubah dalam penelitian ini adalah peranan kemampuan manajerial Kepala Sekolah dalam Rangka Meningkatkan Mutu Pendidikan di SD Kecamatan Mandai Kabupaten Maros.

\section{c. Definisi Operasional Peubah}

Berkaitan dengan judul penelitian ini, maka untk mendapatkan persepsi terhadap maksud dan arah penelitian ini, maka perlu diberikan batasan istilah sebagai berikut: dengan penelitian ini, adalah sebagai berikut:

1) Kepala Sekolah adalah seseorang yang memperoleh tugas tambahan dari seorang guru untuk memimpin suatu sekolah oleh dinas pendidikan.

2) Kompetensi Manajerial merupakan seperangkat kemampuan yang dimiliki oleh kepala sekolah untuk menjalankan tugas dan fungsinya sebagai manajer di Sekolah Dasar yang mencakup perencanaan, pengorganisasian dan pengarahan dalam bidang administrasi pendidikan secara terpadu yang ditampilkan dalam tindakan-nya untuk meningkatkan mutu sekolah.

3) Peningkatan Mutu Pendidikan adalah suatu upaya yang dilakukan berupa pelayanan kepada pelanggan,dalam bidang pendidikan, pelayanan pendidikan, berarti semua perangkat sekolah dari kepala sekolah, guru dan karyawan dan tenaga kebersihan dan melakukan berbagai bidang yaitu, kurikulum, kesiswaan dan proses belajar mengajar.

\section{d.Populasi dan Sampel Penelitian}

Populasi dalam penelitian ini adalah seluruh seluruh guru Sekolah Dasar di wilayah Kecamatan Mandai Kabupaten Maros yang jumlahnya 241 orang guru yang statusnya PNS. Maka peneliti mengambil sampel sebanyak $25 \%$ atau 60.25 dibulatkan menjadi 60 orang guru yang berada pada dilingkungan UPTD Pendidikan Kecamatan Mandai Kabupaten Maros dapat dilihat pada tabel berikut:

Tabel 1. Sampel Guru Sekolah Dasar di Wilayah UPTD Mandai Kabupaten Maros

\begin{tabular}{cllc} 
No. & \multicolumn{1}{c}{ Wilayah } & \multicolumn{1}{c}{ Nama Sekolah Dasar } & Jumlah \\
\hline 1. & Hasanuddin & SDN 99 Kadieng & 5 \\
2. & Bontoa & SDN 24 Batangase & 7 \\
& & SD 179 INP. Batangase & 5 \\
& & SD 103 Hasanuddin & 10 \\
3. & Bonto Mate'ne & SD 178 INP. Bontoa & 8 \\
4. & Baji Mangai & SDN 234 Barambang I & 9 \\
& & SDN Baddo & 5 \\
& & SDN 35 Pao-Pao & 9 \\
\hline & & SDI 222 INP.Pao-Pao & 5 \\
\hline
\end{tabular}

Sumber : UPTD Pendidikan Kecamatan Mandai Kabupaten Maros

\section{Teknik Pengumpulan Data}

Untuk memperoleh data dalam penelitian ini, digunakan pengumpulan data adapun alat pengumpuan data digunakan dalam memperoleh data dalam penelitian ini ada tiga yaitu: a. dokumentasi, b. wawancara dan c. angket.

\section{Teknik Analisis Data}

Analisis data yang digunakan adalah analisis deskriptif bertujuan untuk mengetahui gambaran kebutuhan pengawas sekolah / madrasah akan peningkatan mutu kinerjanya. Teknik analisis yang digunakan adalah analisis persentase dengan rumusan sebagai berikut :

$$
\mathrm{P}=\frac{\mathrm{n}}{\mathrm{N}} \mathrm{---} \text { x } 100 \%
$$

$$
\begin{aligned}
& \text { Keterangan } \\
& \begin{aligned}
\mathrm{P} & =\text { Persentase } \\
\mathrm{n} & =\text { Nilai yang diperoleh } \\
\mathrm{N} & =\text { Nilai yang diharapkan }
\end{aligned}
\end{aligned}
$$

Untuk menarik kesimpulan digunakan pedomanan yang dikemukakan oleh Toha ( 1996) yaitu:

a. Baik $(76 \%-100 \%)$,

b. $\quad$ cukup $(56 \%-75 \%)$,

c. kurang baik $(40 \%-55 \%)$,

d. tidak baik (kurang dari $40 \%$ ). 


\section{HASIL \& PEMBAHASAN}

\section{A. Hasil Penelitian}

Dalam penelitian ini pada bagian pemaparan hasil penelitian digambarkan data yang meliputi: (1) Profil Kepala sekolah, (2) Jenis kelamin, (3) Tingkat Pendidikan. Untuk lebih jelasnya masing-masing karakteristik responden digambarkan seperti uraian berikut:

\section{Profil pengawas menurut tingkatan tugas}

Berdasarkan hasil penelitian yang dilakukan peneliti terhadap responden dalam penelitian ini, diperoleh data tentang profil kepala sekolah di di Kecamatan Mandai berdasarkan tingkatan pendidikan, terdapat 18 sekolah dasar, yaitu 15 orang adalah kepala sekolah dasar negeri, dan 3 orang kepala sekolah statusnya kepala sekolah dasar islam. Dengan demikian dapat disimpulkan bahwa kepala sekolah secara keseluruhan terdapat 18 orang untuk seluruh sekolah berdasarkan Kecamatan Mandai. Gambaran profil kepala sekolah berdasarkan jenis sekolah dapat dilihat pada tabel berikut di bawah ini.

Tabel 2. Profil Kepala Sekolah berdasarkan jenis sekolah

\begin{tabular}{clcc}
\hline No & Jenis & Frekuensi & Persentase \\
& Sekolah & & \\
\hline & SD N & 15 & 83,33 \\
: SDI/DDI & 3 & 16,67 \\
\hline Jumlah & 18 & 100,00 \\
\hline
\end{tabular}

Sumber: Penelitian 2016 pada Kantor UPTD Kecamatan Mandai

Berdasarkan data pada tabel tersebut di atas, dapat disimpulkan bahwa kepala sekolah yang paling banyak jumlahnya ada pada sekolah dasar negeri dibandingkan jumlah kepala sekolah lainnya.

\section{Tingkatan Pendidikan}

Berdasarkan dari data penelitian, menunjukkan bahwa tingkat pendidikan yang dimiliki oleh Kepala sekolah di Kecamatan Mandai berdasarkan jenjang Pendidikan dimana Kepala sekolah itu bertugas, ternyata tingkat Pendidikan yang dimiliki oleh kepala sekolah bervariasi, mulai dari tingkat (1), Sarjana (S1), Magister (S2). Gambaran latar belakang pendidikan adalah sebagai berikut.
Tabel 3. Karakteristik Kepala Sekolah berdasarkan Tingkatan Pendidikan

\begin{tabular}{rlcc}
\hline No & Tingkatan & \multicolumn{2}{c}{ Persentase } \\
\cline { 2 - 4 } & Sekolah & $\mathrm{f}$ & $\mathrm{P}$ \\
\hline 1. & Sarjana (S1) & 13 & 72,22 \\
2. & Magister (S2) & 5 & 27,78 \\
\hline Jumlah & & 18 & 100.00 \\
\hline Sumber: & Berdasarkan & Data & penelitian tahun \\
& 2015
\end{tabular}

Berdasarkan tabel 42 dapat disimpul-kan bahwa yang lebih dominan memiliki tingkat Pendidikan S1 yaitu 15 orang sedangkan yang memiliki tingkat pendidikan S2 5 orang.

\section{B. Pembahasan Penelitian}

Dari keseluruhan data angket tentang peranan kemampuan manajerial kepala sekolah dalam rangka meningkatkan mutu pendidikan di sekolah dasar wilayah UPTD Kecamatan Mandai Kabupaten Maros, maka berikutnya adalah Membahas tentang nilairata-ratanya, hal ini bertujuan untuk mengetahui gambaran dari masing - masing aspek yang terkandung dalam kemampuan manajerial yang dimiliki oleh kepala sekolah khususnya selaku manajer di sekolah masing-masing berdasarkan pendapat responden.

Angket peneliti sebarkan di sekolah dasar yang ada diwilayah Kecamatan Mandai dalam meningkatkan mutu pendidikan meliputi tujuh aspek yaitu seperti tercantum dalam tabel berikut di bawah ini:

Tabel 4. Tujuh Aspek Kemampuan Manajerial

Kepala Sekolah Dasar Di Wilayah UPTD Mandai Kabupaten Maros

\begin{tabular}{llc}
\hline No & $\begin{array}{l}\text { Aspek Kemampuan } \\
\text { Manajerial }\end{array}$ & Skor \\
\hline 1. & Perencanaan & 675 \\
2. & Pengorganisasian & 1352 \\
3. & Pengarahan & 795 \\
4. & Pengawasan & 418 \\
5. & Kurikulum & 1074 \\
6. & Sarana dan Prasarana & 1060 \\
8. & Kegiatan Belajar & 1095 \\
& Mengajar & \\
\hline \multicolumn{3}{c}{ Jumlah } \\
\hline \multicolumn{2}{c}{ Skor Ideal } & 6469 \\
\hline \multicolumn{2}{c}{ Nilai Skor } & 7200 \\
\hline \multicolumn{2}{c}{ Presentase } & 89.84 \\
\hline \multicolumn{2}{c}{ Keterangan } & Baik \\
\hline
\end{tabular}

Sumber : Penelitian tahun 2016 
Setelah diadakan penelitian dengan menggunakan angket selanjutnya di analisis dengan presentase dengan menggunakan tabel frekuensi yang jumlah responden 60 orang responden. Dari tabel di atas menunjukkan bahwa persepsi guru tentang kemampuan manajerial kepala sekolah dasar di wilayah UPTD Kecamatan Mandai dalam meningkatkan mutu pendidikan memiliki nilai $89,84 \%$ dengan demikian untuk kompetensi kepala sekolah menunjukkan kategori baik. Ini berarti bahwa kompetensi kepala sekolah dalam komponen manajerial baik dalam meningkatkan mutu pendidikan dilihat dari latar belakang kepala sekolah sudah ada yang memiliki pendidikan S2 meskipun masih ada yang sarjana. Untuk lebih jelasnya dapat dilihat dalam gambar berikut di bawah ini.

Gambar 1 Gambaran Kemampuan Manajerial Kepala Sekolah

Di Wilayah UPTD Mandai Kabupaten Maros

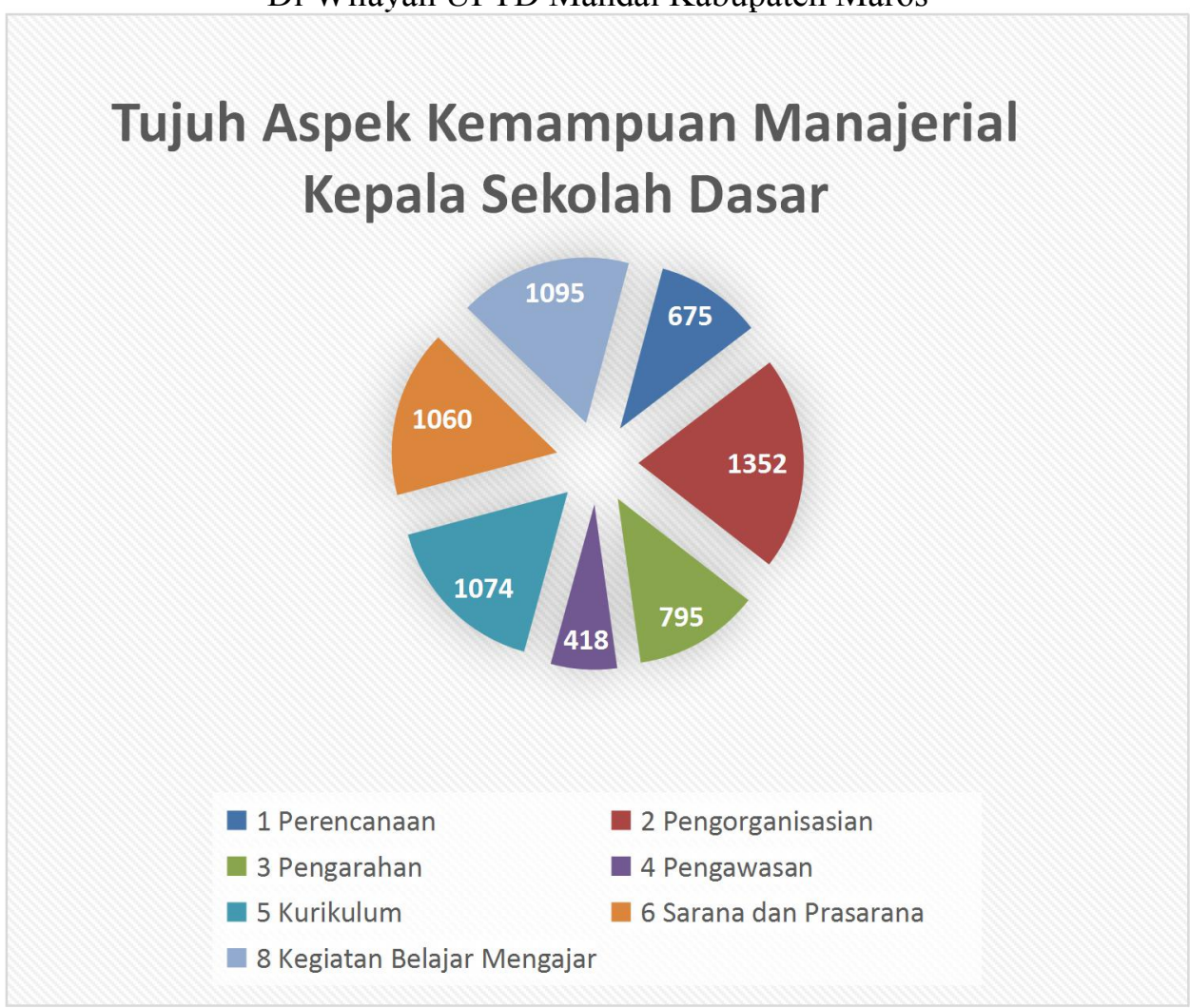

Sumber : Hasil Olah Data angket.

Peran kepala sekolah sebagai manajer dimana berdasarkan data yang peneliti peroleh kepala sekolah sudah mampu membuat perencanaan, pengorganisasian, pengarahan , pengawasan. Sebagai manajer, kepala sekolah Dasar diwilayah UPTD Kecamatan Mandai Kabupaten Maros selalu membuat perencanaan sesuai dengan program kerja tahunan dan kepala sekolah juga selalu Memberikan pengarahan kepada guru dan ditindaklanjuti dengan mengevaluasi kegiatan belajar mengajar. Oleh karena itu, peranannanya sebagai manajer sekolah, bahwa kepala sekolah juga selalu Memberikan pengawasan kepada guru..

Dalam meningkatkan mutu sekolah atau mutu pendidikan di wilayah UPTD Mandai Kabupaten Maros ada beberapa faktor yang mempengaruhi mutu pendidikan, seperti kurikulum, sarana dan prasarana sekaligus kegiatan belajar mengajar.

Dari segi kurikulum, dimana kurikulum adalah serangkaian kegiatan yang dirancang oleh sekolah bagi seluruh siswa dengan tujuan untuk perkembangan siswa dalam mengikuti pendidikan di sekolah. Baik berkaitan dengan intrakurikuler dan ekstrakurikuler. Secara umum kurikulum digunakan sesuai aturan Departemen Pendidikan dan Kebudayaan dengan cara memperkaya kurikulum ada dengan menggunakan metode pembelajaran inovatif sehingga siswa dapat melaksanakan dan mengamalkan pengetahuannya yang telah diperoleh di sekolah dalam kehidupannya sehari-hari. Siswa secara leluasa dapat belajar serta bekerja dengan ditopang oleh sarana atau 
fasilitas yang ada sehingga siswa dapat bergerak bagi mereka untuk keteladanan antara guru dengan siswa, siswa dengan siswa lainnya dalam hal ini guru sebagai fasilitator seperti tertuang dalam visi, misi dan tujuan sekolah masing-masing yang dipimpinnya

Berkaitan dengan sarana dan prasarana yang ada di masing-masing sekolah cukup memadai. Dengan adanya sarana dan prasarana ini menjadikan proses belajar mengajar menjadi lebih efektif. Selain itu, dengan adanya sarana yang memadai dapat mudah untuk meningkatkan mutu pendidikan dan otomatis dapat meningkatkan kualitas sekolah dan akhirnya output sekolah dapat meningkat pula. Dalam proses pembelajaran (PBM) guru telah melaksanakan fungsinya sesuai dengan tugas di kelasnya masing-masing. Artinya seluruh guru telah melaksanakan kompetensinya sesuai data wawancara dengan kepala sekolah dan guru tempat penelitian.

Selanjutnya upaya yang dilakukan oleh kepala sekolah dalam rangka meningkatkan mutu pendidikan berupa upaya Memberikan pelayanan kepada pelanggan, dalam bidang pendidikan semuan perangkat sekolah mulai dari kepala sekolah, guru sampai petugas sekolah harus benar-benar memiliki budaya pelayanan yang baik untuk siswa, orang tua murid sehingga pelanggan dapat merasa puas, bukan hanya setelah lulus tapi juga sejak dari awal mereka masuk halaman sekolah mereka akan nyaman, aman dan terasa terlindungi dan dihargai sekaligus terlayani oleh perangkat sekolah. Dengan demikian upaya yang dilakukan oleh kepala sekolah sehingga mutu pendidikan dapat tercapai melalui:

1. Dalam bidang kurkulum, kepala sekolah bekerja sama dengan guru-guru untuk membenahi perangkat dan pembagian tugas guru sesuai dengan jadwal sampai mengawasi kegiatan belajar mengajar

2. Upaya lainya adalah dengan meningkatkan kualitas sumberdaya manusianya.

Dengan cara meningkatkan prestasi siswa, Memberikan bimbingan belajar kepada anak didik dan mendisiplinkan anak didik.

\footnotetext{
KESIMPULAN \& SARAN

A. Kesimpulan

Gambaran peranan kemampuan manajerial kepala sekolah dasar dalam meningkat mutu pendidikaan di wilayah UPTD Kecamatan Mandai Kabupaten Maros, termasuk kategori baik, untuk lebih jelasnya dapat dilihat pada aspek-aspek sebagai berikut:
}

1. Kepala sekolah dasar di Wilayah UPTD Mandai Kabupaten Maros dalam melaksanakan kompetensinya pada kategori baik ( mampu) atau $89.84 \%$ secara ratarata sehingga dapat berguna dalam meningkatkan mutu pendidikan.

2. Dalam aspek perencanaan kemampuan kepala sekolah dikategorikan baik yaitu 93,75\%,sedangkan pada aspek kemampuan mengorganisasikan kegiatan sekolah juga termasuk kategori baik yaitu 93,88\%, dalam Memberikan pengarahan dikategorikan baik pula meskipun dari unsur ini masih ada yang belum maksimal karena masih ada yang mengkategorikan cukup $(57,08)$ dalam memberikan pengarahan kepada guru yang mempunyai kesulitan dalam proses belajar mengajar, sedangkan untuk aspek kemampuan pengawasan termasuk kategori baik (87.08\%), sedangkan dalam aspek kurikulum dikategorikan baik $(89.50 \%)$ dan aspek sarana dan prasana juga termasuk kategori baik (88.33\%), demikian pula dalam menerapkan upaya peningkatan mutu pendidikan termasuk kategori baik pula atau $91.25 \%$.

\section{B. Saran-Saran}

Berdasarkan hasil penelitian di atas, maka penulis sarankan sebagai berikut:

1. Kepala sekolah diharapkan dapat meningkatkan kompetensi dalam bidang manajerialnya dari yang sudah baik menjadi lebih baik lagi dengan apa yang diperoleh saat ini, hal ini tentunya telah dipeoleh karena adanya kerja keras dan kerjasama dengan berbagai pihak dan kepala sekolah jangan merasa puas dengan apa yang telah diperoleh namun selalu tetap menjaga dan mau meningkatkan kembali agar kualitas pendidikan yang dicapai khususnya disekolah yang dipimpinnya dapat dipertahankan

2. Dalam hal ini kepala sekolah harus meningkatkan kerjasama dengan guru untuk meningkatkan tugas manajerial yang efektif.

Guru Sekolah Dasar yang berada di wilayah UPTD Kecamatan Mandai harus selalu Memberikan masukan kepada kepala sekolah dalam pelaksanaan tugas manajerial dimulai dari tahap perencanaan sampai pengawasan secara bersama-sama meningkatkan tatakelola sekolah sebagai upaya meningkatkan mutu pendidikan di sekolah masing-masing. 


\section{DAFTAR PUSTAKA}

Akdon, 2004. Estimasi Kinerja Manajemen Melalui Kapabilitas Organisasi Dalam Implementasi

Kebijakan Desentralisasi Pendidikan. Disertasi. Bandung: Pasca Sarjana UPI

Amiruddin. Dkk. 2006. Manajemen PendidikanBerbasis Sekolah.Ciputat: QuantumTeaching (Ciputat Press Group).

Arikunto, Suharsimi. 2006. Prosedur Penelitian Suatu Pendekatan Praktik, Edisi Revisi VI. Jakarta: Rineka Cipta. 1998.Prosedur Penelitian Suatu Pendekatan Praktik, Edisi Revisi VI, Jakarta: Rineka Cipta.

Azizy, A. Qodry.2002. Pendidikan (Agama) untuk Membangun Etika Sosial, Semarang:Aneka Ilmu.

Danim,Sudarwan Suparno.2009 .Manajemen dan Kepemimpinan Transformasional Kekepalasekolahan Visi dan Strategi Era Teknologi, Situasi Krisis, dan Internasionalisasi Pendidikan, Jakarta: RinekaCipta.

$\begin{array}{lcr} & \\ \text { Nomor 12 } & \text { Tahun 2007 } & \text { Tentang } \\ \text { Kualifikasi } & \text { dan } & \text { Konpetensi } \\ \text { Pengawas } & \text { Sekolah. } & \text { Jakarta: } \\ \text { Depdiknas } & & \end{array}$

Engkoswara \& Komariah.A. 2010. Administrasi Pendidikan. Bandung: Alfabeta

Fattah,Nanang. 2009. Landasan Manajemen Pendidikan. Bandung: Remaja Rosdakarya.

Hikmat. 2009. Manajemen Pendidikan. Bandung: PT Pustaka Setia

Manullang, M.2006. Dasar-dasar manajemen.Yogyakarta: Gadjah Mada University Press, Cet- XIX.

Mulyasa, E. 2004. Kurikulum Berbasi Kompetensi Konsep karakteristik dan Implementasi. Bandung: Remaja Rosdakarya.

----------, 2007. Menjadi Kepala Sekolah Profesional dalam Kontek Menyukseskan MBS dan KBK. Bandung: Remaja Rosdakarya.

Muslich, Masnur. 2009. KTPS (Kurikulum Tingkat Satuan Pendidikan) Dasar Pemahaman dan Pengembangan. Jakarta: Bumi Aksara, Cet-V.

Purwanto, Ngalim, M. 2004. Administrasi dan Supervisi Pendidikan. Bandung: Remaja Rosdakarya.
Raihani, 2010. Kepemimpinan Kepala Sekolah Transformatif. Yogyakarta: LKiS Printing Cemerlang,

Ramayulis. 2004. Ilmu Pendidikan Islam, Jakarta: Kalam Mulia.

Rosyada, Dede. 2007. Paradigm Pendidikan Demokrasi Sebuah Model Pelibatan Masayarakat dalam Penyelenggaraan Pendidikan, Jakarta: Kencana Prenada Media Group, Cet-III,

Suparta, M dan Noer Aly, Herry.2002. Metodologi Pengajaran Agama Islam. Jakarta: Amissco Jakarta.

Sadiman, S. Arief, Dkk. 2009. Media Pendidikan,Pengertian, Pengembangan,dan Pemanfaatannya. Jakarta: Rajawali Pers.

Sallis,E. 2000. Total Quality Management Education. London:Kogan Page

Soemanto,W. 2006. Psikologi Pendidikan Landasan Kerja Pemimpin Pedidikan.Jakarta: Asdi Mahasatya, Cet$\mathrm{V}$

Sudjono, Anas . 2010. Pengantar Statistik Pendidikan. Jakarta: Raja Grafindo Persada,Cet-XXII.

Syaefudin, Udin dan Syamsuddin Makmun, Abin. 2009. Perencanaan Pendidikan Suatu Pendekatan Komprehensif. Bandung: Remaja Rosdakarya, Cet-IV.

Uwes, Sanusi, 2010. Visi dan Pondasi Pendidikan (dalam Perspektif Islam), Logo: Wacana Ilmu.

Wahjosumidjo. 2010.Kepemimpinan Kepala Sekolah Tinjauan Teoritik dan Permasalahnnya. Jakarta: Rajagrafindo Persada. 